\title{
E-GOVERNANCE AND THE NIGERIAN TAX ADMINISTRATIVE SYSTEM
}

\author{
Catherine Enoredia Odorige ${ }^{1}$
}

\begin{abstract}
Nigeria like most countries who were 'unfortunate' to have rich deposits of natural resources has been 'battered' greatly by the economic paradox known as resource curse. Dependence on oil exploration and export meant that politics was played with taxation which remains the oldest and most recognized form of generating revenues for the provision of infrastructures and smooth running of the state. The global fall in crude oil prices, high rates of unemployment and agitations from the population for improved service delivery, has awakened the government to the fact that the days of treating tax revenue collection as favour to political faithful are over.
\end{abstract}

This paper takes a look at the application of information technology efforts by the Nigerian government towards reinforcing revenue generation. It will analyze how the present use of information technology in Tax administrative system has helped to check hitherto exploited loopholes of the revenue administration and to make recommendations towards improvements.

\section{Introduction}

Taxation remains the oldest and main source of revenue generation for most economies in the world. Oldest in the sense that before Adam Smith conceived of his Wealth of Nations in 1776, there were already records of the Roman taxation system. (Donald 1974). The 40 percent tax paid by the ancient Hebrews to Rome during the time of Christ was reason enough for why they sort for a messiah that will deliver them from this bondage. ${ }^{2}$ Historians reported a heavier burden on the French of 81 percent on their income prior to their famous revolution. ${ }^{3} 17^{\text {th }}$ century consumption tax in Britain is what is today known as customs and excises, where every consumable were taxed as ministers of finance were constantly under pressure to supply more funds as Britain was at war. ${ }^{4}$ Prior to industrial revolution in mid- $19^{\text {th }}$ century, feudal custom rights made for a compulsory toll fee on traders' goods payable at the frontiers on the Weser-Elba water ways. Within every 12 kilometer there was an average of eight tolls payable over 240 kilometers between Milan to Florence. Marjan (2014).

The Nigerian nation is not left out among nations who depended on taxation as a source of revenue generation in order to be able to meet with the needed revenue for the operation of the state, though the discovery of crude oil was diversionary. As the envisaged big bucks coming from the 'liquid gold' as crude oil was popularly called, did not allow for efficient tax collection especially in a system rife with corruption.

\footnotetext{
${ }^{1}$ National University of Public Service Budapest, Hungary.

${ }^{2}$ Curran J. Donald (Ed) (1974) Tax Philosophers: Two Hundred Years of Thought in Great Britain and the United States, London United Kingdom, The University of Wisconsin Press.

${ }^{3}$ Ibid

${ }^{4}$ Ibid
} 
E-governance and public administration has brought about efficiency and transparency in the delivery of public service in developed nations. Nigeria has in the millennium age begun to apply the internet to public administration and this is beginning to make a difference in the way taxation is perceived and administered.

\subsection{Definitions of Taxes}

Taxes are defined as general or involuntary fees levied on individual or corporations, by the government entity whether local, regional or national in order to finance government activities. In economics taxes fall on whoever paid the tax burden, the entity being taxed like a business or end consumers of the business goods. ${ }^{5}$ Tax is also regarded as the citizen's share of the government's burden. Taxation is the means by which resources are made available for the provision of public good which benefits the populace. Such public goods are the provision of infrastructure public health and the maintenance of law and order. ${ }^{6}$ Taxation refers to the enforced proportional levies imposed on the persons and properties by the state by virtue of its sovereignty ${ }^{7}$. The origin of the word is traced to the Latin word 'taxare' which means to estimate... someone's wealth or the price of certain goods for the purpose of taxing them. Marjan (2014). Taxation as an economic policy could support preferred activities by a targeted tax regime and roll back others by higher taxation. Marjan (2014). Regular classification of taxes is by direct taxation paid directly to the government on the persons on whom it is imposed. And indirect taxes collected by proxy such as the retail store from the consumer. ${ }^{8}$ Nigeria by virtue of her sovereignty apply taxation on its citizens to generate funds for governance as enshrined in the constitution, but scholars have pointed to the nondefinition of the term taxation by the tax laws of Nigeria invariably taking it for granted that all ought to know what taxation means ${ }^{9}$.

\section{Pre-colonial Tax Systems}

Taxation in Nigeria pre-dates the colonial era. Kingdoms and communities which according to Sir Hugh Clifford the Governor General of Nigeria between 1923-1956 are a collection of independent Native states, separated from one another by great distances, by differences of history and traditions and by ethnological, racial, tribal, political, social and religious barriers. (Anuforo, 2013: Pp1\&2). ${ }^{10}$ This narrative was evident in the larger groups of the Hausa-fulani kingdom, Yoruba kingdom, Igbo kingdom, Benin kingdom, Nupe kingdom and the several minority groups like the Idomas, Tivs, Ijaws, Urhobos, Itsekiris, and Ibibios. They each had developed forms of levies, taxation on their 'citizens' for the needed revenue to be able to meet the day to day running of their kingdoms. These taxes come in form of 'zakkat' 'kudin-kasa' 'shuka-shuka' belonging to the Hausa-Fulani northern part of Nigeria, 'ishakole' 'owo-ori' to the Yoruba of western Nigeria. ${ }^{11}$ The tradesman ship of the Benin kingdom in crafts and artifact produced by craftsmen and administered by the various groups

\footnotetext{
${ }^{5} \mathrm{http}: / /$ www.investopedia.com/terms/t/taxes.asp retrieved 20 November 2016

${ }^{6}$ OECD (2014), "Fundamental principles of taxation", in Addressing the Tax Challenges of the Digital Economy, $26^{\text {th }}$ November 2016

7 Thomas Cooley M. (1879), A Treaties of Law of Taxation: Including the Laws of Local Assessments, Chicago, Callaghan.

${ }^{8}$ Marjan Attila (Ed), (2014), European Economic and Monetary Integration, Budapest, Hungary. National University of Public Service.

${ }^{9} \mathrm{http}: / /$ www.nigeria-law.org/BusinessInNigeriaTaxation.htm https://eirs.gov.ng/tax-law/ retrieved $10^{\text {th }}$ December 2016.

${ }^{10}$ Cited in Negedu Isaiah and Atabor Augustine, Nationalism in Nigeria; A Case of Patriotic Citizenship, American Journal of Contemporary Research, Vol. 5 No.3 June 2015. Retrieved $12^{\text {th }}$ June 2016

${ }^{11}$ ICAN, Introduction to Nigerian Tax System.
} 
of 'iwebo' 'iweguae' and 'ibiwe'. They oversee to the provisions of the palace and the community needs from resources realized from trade, tributes and levies from the people and smaller communities who hold allegiance to the Benin kingdom. ${ }^{12}$ These disparate groups were brought under one nation called Nigeria in1914.

\subsection{British -Colonial Tax Administrative System}

Tax administration under colonialism was by 'rule of the thumb'captured by Malecki (1991) that colonies were made by and for the mother country with primary development of natural resourse of the colonies for the mother country. Taxes was on individuals, properties and co-operate entities. Financial statements for individuals (income tax), financial statements for businesses (corporate tax) were not developed and this created room for sharp practices by tax administrators and resentments by the public which led to the various unrests like the Aba women's riot of 1929 and the Agbekoya riots of $1969^{13}$ The Raisman Commission, introduced the uniform basic income tax principles subsequently incorporated into the 1960 independence constitution of Nigeria, leading to the promulgation of the income tax act and the company tax act of $1961^{14}$,

\subsection{Post-colonial Tax System}

Nigeria discovered crude oil on January 151956 in Oloibiri in Ogba local government area of Bayelsa state in the Niger-Delta by Shell Bp- petroleum ${ }^{15}$. Prior to this discovery agriculture was her economic mainstay. Agricultural production gave Nigeria an enviable record of food sufficiency as well as placing her in the limelight of global trade and exports (Oluwasanmi 1960: 34-36) ${ }^{16}$. Mangrove region of southern Nigeria with high rainfall per annum supports the growth of palm trees, rubber, coffee and cocoa etc. The savannah grassland to the north supports the planting of cereal and leguminous crops such as sorghum, millet, ground nuts (groundnut pyramids in Kano) as well as animal rearing mostly for hide and skin Ekundare (1973:55-56 ${ }^{17}$ ) Palm oil had been an export commodity in Nigeria as early as 1558 , (Olukoju 2009:105-125). ${ }^{18}$ Cotton joined the export list in 1856, while cocoa from western Nigeria made its debut in 1874; Oyedele $(2007)^{19}$. Revenue from agriculture was appropriately used to build landmark social and economic infrastructure, providing basic services like education, health, water and electricity supply, and gave the country tremendous self-sustaining growth. Agriculture met up to $95 \%$ of the food needed to feed Nigerians and contributed 64.1\% Gross Domestic Product (GDP) and employed over 70\% of Nigerian

\footnotetext{
12 Osagie Joseph and Ikpomwosa Frank, (2015), Craft, Guild and the Sustenance of Pre-colonial Benin Kingdom, International Journal of Arts and Humanities, (IJAH) Bahir-Dar Ethiopia Vol. 4(1), S/No 13, retrieved $24^{\text {th }}$ December 2016

${ }^{13}$ Oseni Michael, (2015) Sustenance of Tax Administration by Information and Communication Technology in Nigeria, Archives of Business Research 4 (1) 47-54

14 Ibid

${ }^{15} \mathrm{http}$ //www.nnpcgroup.com/NNPCBusiness/Businessinformation/OilGasinNigeria/IndustryHistory.aspx retrieved $28^{\text {th }}$ November 2016

${ }^{16}$ Oluwasanmi, H.A. (1960), Agriculture and Nigerian Economic Development, Ibadan, Oxford University Press.

17 Ekundare, R.O. (1973). An Economic History of Nigeria, 1860-1960: London Great Britain, Richard Clay the Chaucer Press LTD.

${ }^{18}$ Olukoju, K.,(2009), "The United Kingdom and the Political Economy of Global Oils and Fat Business during the 1930," Journal of Global History, Vol. 4, (1) 1.

${ }^{19}$. Oyedele, J.O., (2007), Enhancing the Sustainability of Cocoa Growing in Nigeria. A Paper Presented at the ICCO Roundtable Congress on Sustainable World Cocoa Economy at Accra, Ghana. $3^{\text {rd }}-6^{\text {th }}$ October. Cited in Ndubuto Ifeanyi Nwanchukwu, et'al, Competitiveness and the Determinants of Cocoa Export from Nigeria http://www.sciencepub.net/report/report0207/08_3470report0207_51_54.pdf. Retrieved 28 ${ }^{\text {th }}$ November 2016
} 
population before oil exportation commenced (Oluwasanmi 1960: 23-29) ${ }^{20}$. In the later years, rubber and Bennie-seed followed as major valuable cash crops. These cash crops were the main source of revenue, export and foreign exchange for the government (Udo 1967: 18). ${ }^{21}$

Military incursion into politics from 1966 and the absence of parliamentary deliberations and decisiveness needed to wade in to stop the descent into mono product dependence, allowing the country to gradually slide into export dependence which brought about vast unemployment. Lack of accountability in military dictatorships entrenched corruption, and promoted the wasteful and unimpactful execution of elephant projects. Military regimes lacked administrative direction for the relationship between tax collection and the provision of social amenities like electricity, pipe-borne water, good road connectivity security of lives and property for its citizens. In a survey by James Abiola and Moses Asiweh $(2010)^{22}$, there seem to be a clear demotivation to pay taxes due to the fact that the need to pay taxes was unobvious because the state was derailing on her role to provide social and infrastructural needs for the population.

\section{Tax Governance}

Tax administration in Nigeria is divided between the three levels of government authorities with each having an area of jurisdiction for which it collects taxes:

- Federal Inland Revenue Service, (FIRS) is the federal arm. It's area of tax jurisdiction are Companies income tax and Personal income tax of federal civil servants, military and paramilitary residents of the federal capital territory, staff of ministry of foreign affairs and non- resident individuals, Petroleum Profit Tax, Value-added tax (VAT), Education tax, Capital gains tax for Abuja (the capital of Nigeria) residents and corporate bodies, withholding tax, Stamp duties involving corporate entity

- $\quad$ State Internal Revenue Service (SIRS) the state arm, collects the following taxes: Personal income tax, Capital gains tax, Stamp duties, toll fees, Pools betting, lotteries, gaming and casino taxes, Business premises registration and renewal levy, as defined by each state, development levy with a recommended registration fee of 10,000naira average of 30dollars and 5000naira annually, an average of 15dollars, certificate of occupancy, (paid on private properties usually for a period 99years), fees for granting street name, and markets stall rates and consumption tax (recently adopted by some states in the federation)

- The Local Government Revenue Committee (LGRC) collects taxes in the following areas: Tenement rates, shops/kiosks levies, liquor license, abattoir fees, Marriage/birth/death registration fees, local market/motor park fees, domestic animal license, Bicycle, truck, canoe, wheelbarrow and cart fees, Cattle tax, 'merriment' and road closure fees, (a fee for the granting of permission to part(s) of a road for the purpose of a ceremony, merriment here is in

\footnotetext{
${ }^{20}$ Cited in Paul Ilesanmi Akanmidu, (2015) A Historical Perspective of Petroleum on Nigeria's Economic Crisis since Independence, Global Journal of Human and Social Science. Inc. USA ISSN2249-460X E-Economics. Retrieved 20 ${ }^{\text {th }}$ December 2016

${ }^{21}$ Udo R.K.,(1967). "British Policy and the Development of Export Crops in Nigeria Nigerian Journal of Economic and Social Studies, 9, 2 retrieved $12^{\text {th }}$ December 2016

22 James Abiola and Moses Asiweh, (2012) Impact of Tax Administration on the Government Revenue in a Developing Economy: A case Study of Nigeria International Journal of Business and Social Science Vol. 3 No. 8 [Special Issue April 2012 Retrieved $29^{\text {th }}$ November 2016
} 
parenthesis because ceremonies are not only for merriment purposes), parking/default parking charges, Public convenience, sewage and refuse disposal fees, burial ground and religious places permits; and Signboard/advertisement permit. ${ }^{23}$

These three tiers of tax governance in the country also collaborate under the auspices of the Joint Tax Board. The structure of the Nigerian tax system is divided into a tax policy, tax legislation and tax administration. The tax policy gives structure to the national tax system and it forms the base of tax laws. Tax legislation is the deliberations of choices and directions to take and it provides the legal backing that makes the tax laws effective and authoritative. Finally tax administration is the implementation aspect of the national tax system.

Some of the challenges of the tax administration are:

- Tax evasion and avoidance

- $\quad$ Poor compliance or under reporting

- Failure in tax administration and enforcements

- $\quad$ Corruption and rule of the thumb

- Incidences of fake tax administrators

- $\quad$ Lack of effective operational tools.

- Double taxation of individuals and corporate entities due to issues of jurisdiction of the various tiers of government in the business of tax collection.

- $\quad$ Lack of a comprehensive data base for citizens identification is a challenge

The state of decadence of the challenge of tax avoidance and evasion is best captured in the briefing by the Chairman of the Independent Corrupt Practices Corporation ICPC Mr. Ekpo Nta before the senate committee on drugs, narcotics financial crimes and anti-corruption when he reported that out of 156 contractors with the federal ministry of works 50 operated with fake tax certificates, this represents one third equal to $32 \%$ forgery found in one agency alone (Vanguard Newspapers editorial 2015) ${ }^{24}$. This is a testimony of the level of loss in taxation. These are contractors dealing with government agencies. Imagine those whose direct clientele has no relationship with government! This will be more because there is less fear of being checked or caught.

According to Lopez and Kadar $(2001)^{25}$ taxation among Organization for Economic Development Countries (OECD) had uniformly been geared towards efficiency, increased tax revenue, equity and

\footnotetext{
23 Taxes Levies Approved (list of collection) Decree № 21 of 1998 Laws of the Federation of Nigeria http://www.nigerial-law.org/Taxes\%20and\%20Levies\%20(Approved $\% 20$ list $\% 20$ for $\% 20$ collection) $\% 20$ Decree $\% 20 \mathrm{No}$ $\% 2021 \% 20$ of $\% 201998 . h$ tm

${ }^{24}$ Cited in Oseni Micheal, (2016), Sustenance of Tax Administration by Information and Communication Technology in Nigeria, Archives of Business Research 4 (1) 47-54

${ }^{25}$ Lopez, A. and Kadar, Z (2001) "Introduction". International Tax Review: World Tax 2002, 1st Jan: 6-11Cited in James Abiola and Moses Asiweh, 2012) Impact of Tax Administration on the Government Revenue in a Developing
} 
enforceability. This may not be unconnected with the level of growth and development in these countries. But much is still left to be desired with regards to tax administration in Nigeria and the function it is supposed to serve. Put succinctly by Nightingale $(2002)^{26}$ it is payment imposed by government while taxpayers may receive nothing identifiable in return for their contribution." Much as the citizens should not expect that government must do something within the locality of the taxpayer because of his tax contribution - Osunkoya (2009) $)^{27}$, evidence of taxation as seen in public infrastructures encourage the taxpayer. Infrastructural decay account for the high rate of tax evasion which is assumed to be exploitative as against a means of growth and development.

\section{Theories of taxation}

Literature on taxation dates back to the middle of the seventeenth century British society, focusing on her international growth and furthering export and favourable balance of trade. Much debate focused on whether high or low wages was more advantageous as a strategy for success in the international rivalry. These were the days of Benefit theory of taxation which says that a person or corporation should pay for what he gets. Benefits were measured by consumption. Hobbes in his Leviathan, "The equality of imposition 'consisteth' rather in the quality of that which is consumed than of the riches of that which consume same. In the same vein these other writer stress taxes on luxuries. Sir William Petty and Thomas Mun summarize their theory of 'you can't take a shirt of a naked man'. In Adam Smith's Wealth of nations he avers that governments spend other people's money and lack the self-interest motive. Much as Smith is no anarchist and recognizes the relevance of government to the society, his bias with that of other classical economists against government was obvious and informs his formulation of the maxims of taxation.

a. Taxes should be equal and equitable-joint tenant of a great estate.

b. Certain and not arbitrary- clear and plain not subject to extortion

c. Convenient - timing and manner

d. Economical- not too expensive that will be discouraging to the taxpayer ${ }^{28}$

\subsection{The Ability to Pay Theory}

This has been described as progressive taxation; collectable from those that has and must be seen as a sacrifice on the part of the payer. ${ }^{29}$ Similar to the proportionate principle promoted by John Stuart Mill, proportionality should determine tax rating, to achieve equality of sacrifice. ${ }^{30}$ This is the Pay As You Earn, PAYE principle prevalent in tax administration.

Economy: A case Study of Nigeria International Journal of Business and Social Science Vol. 3 No. 8 [Special Issue April 2012

${ }^{26}$ Nightingale, K. (2002) Taxation theory and practices. England, Pearson Education Ltd.

${ }^{27}$ Osunkoya, D (2009) "Nigeria Tax system needs autonomy". Retrieved 19th Dec. Available from:

http://234next.com/csp/cms/sites/Next/Money/Finance/5499086-147/story.csp.Cited Ibid

${ }^{28}$ Curran J. Donald, (Ed) (1974), Tax Philosophers, Two Hundred Years of Thought in Great Britain and the United States, London, The University of Wisconsin Press.

${ }^{29}$ Kendrick Slade, (1939), Ability to Pay Theory of Taxation, America Economic Association, Vol. 29, No. 1 (Mar., 1939), pp. 92-101 URL: http://www.jstor.org/stable/1806989

${ }^{30}$ Ekelund B. Robert and Walker M. Douglas, (1996), J. S. Mill On the Income Tax Exemption and Inheritance Taxes: The Evidence Considered http://piketty.pse.ens.fr/files/EkelundWalkeronMill(HPE1996).pdf Retrieved 25 $5^{\text {th }}$ December 2016 


\subsection{The cost of Service Theory}

The cost of Service Theory of taxation focuses on the idea of equity and justice in its proposal that cost of services should be equivalent to tax paid but this principle has been rejected on the ground that there is no quid pro quo in taxation as there is no way of measuring the cost of police, judiciary, armed forces, prisons services and the many other services rendered by government that cannot be quantified $^{31}$.

\subsection{Taxation in Developing Countries}

The public finance literature focuses on the optimal rates structure under the personal income tax as a means of best trading off equity and efficiency consideration in the collection of taxes. Gordon (2010) in a research carried on six developing countries discovered that this assumption is only characteristic of developed nations as the results of the research showed that personal income tax plays little role. They presumed that this phenomenon is as a result of the inability of the tax agencies to monitor the income accrual to individuals to make judgments on deductions, as a result income tax is not exploited to advantage in developing countries. Tax revenue is mostly from value added tax (VAT) also heavily applied in developed nations, commonly cushioned by safety net programmes for the poor, virtually non-existent in developing countries; therefore tax burden on the poor is more. Taxation that is ill-developed in terms of income, is connected to low level information technology usage in these developing nations.

\section{Technology and Efficient Tax Administration}

The internet, a complex technological system consisting of the communication backbone, the local access point, local network and packet switches and terminals for the connectivity of individuals with various internet capable devices transmit signals that are reassembled at the destination, Kogut (2003). ${ }^{32}$ On the American digital economy Moulton (2000) describes as perfect capture of the economic statistics on earnings from production and benchmarked to tax administrative data. Efficiency and profits are key determinants in the adoption of new technologies. Mokyr (2002). The essential feature of cyberspace is connectedness and aims at breaking down boundaries and walls. Rifkin (2000). Information technology in the form of knowledge based economy with the potential of blurring distance comes as an ever pressing need to align national strategies with world-wide movements towards a global information society UN 2000. If taxation is to the nation what blood is to the individual, Cooley (1881). ${ }^{33}$ diverted by the by the availability of natural resources, described as the resource curse by scholars because of the rent seeking attitudes that natural resource has generated in many nations, 'so-blessed' Nigeria being one of them. ${ }^{34}$ Regardless of Deacon (2011) position that common sense and simple economics imply that natural resource abundance should confer benefits, yet, Nigeria's per capita GDP in 2000 was $30 \%$ lower than in 1965 , despite oil revenues of roughly $\$ 350$ billion. Anecdotal sounding statement like this one by Bill Clinton "With its vast human and natural resources, a revitalized Nigeria can be the economic and political anchor of West Africa ...... United States Bill Clinton” Sheik Ahmed Yamani, former Oil Minister

\footnotetext{
${ }^{31} \mathrm{http}: / /$ economicsconcepts.com/theories_of_taxation.htm

${ }^{32}$ Kogut Bruce, The Global Internet Economy, London, United Kingdom MIT Press, Cambridge Massachusetts (200)

${ }^{33}$ Cooley, Thomas M. "Remedies of Illegal Taxation." Am. L. Reg. 29 (1881): 1-16.

34 Deacon T. Robert, (2011), The Political Economy of Natural Resource Curse: A Survey of Theory and Evidence. Hanover USA, Now Publishers Incorporated. http://www.nowpublishers.com/article/Details/MIC-042
} 
of Saudi Arabia: "All in all, I wish we had discovered water." Ross (1999) ${ }^{35}$ Administrative changes from the reform perspectives is the result of deliberate goal oriented choices. Brunsson and Olsen (1993). Conscious changes have to be applied to the Nigerian tax administration as part of efforts to revitalizing her economy.

\subsection{New ICT Tax Administration Applications in Nigeria}

The application of information technology is changing the phase of Nigerian administration systems, with the country's development of an information technology policy since January $2000^{36}$, acknowledging the vital role ICT plays in the nation's development plan. The federal inlandrevenue service, the body charged with the responsibility for tax administration has since keyed into this policy plan. More practical steps have been applied by the board to change the way Nigerians can access tax payments electronically. A significant synchronization of tax administration in Nigeria is the introduction of TIN (Tax Identification Number. A computer generated unique identifier which has the ability to drag all taxable Nigerians into the tax net. The website design of the FIRS and some states webpage show how payments can be made for various types of taxes. Much as websites of some Nigerian agencies, parastatals and ministries have been categorized as primarily for public affairs, UN (benchmarking and e-government 2002) ${ }^{37}$ the FIRS cannot afford to play public affairs with its websites because efficient and result oriented tax administration depends on proper working of icons on its webpage. ${ }^{38}$ But some states web online tax administration is more advanced than others an example is the Edo state webpage where you are can get the TIN number on first visit to the webpage by filling in a couple of information. ${ }^{39}$

The major turn in tax administration in Nigeria took place in 2007 with the granting of financial and administrative autonomy to the Federal Inland Revenue Service through the Establishment Act 2007. Changes in tax administration since 2004 cuts across states and federal authorities by way of organizational restructuring, enactment of national tax policy, funding, legislation, tax education, dispute resolution mechanism, taxpayer registration, human capacity building, automation of key processes, refund mechanism and several other areas discussed in the in the handbook of FIRS taxation reforms $2012 .{ }^{40}$ The positive results of these changes in application is obvious from the dramatic changes in the figures from 2004 in the publication of the World Bank/International Monetary Fund government statistics yearbook and data files, World Bank and OECD GDP estimates. $^{41}$

\footnotetext{
${ }^{35}$ This statement was erroneously credited to a William J. Clinton in this article as the president of the United States of America, but it was Bill Clinton that was the President of America at this time and he visited Nigeria in the year 2000 with his daughter, Chelsea.

${ }^{36} \mathrm{http}: / /$ portal.unesco.org/en/ev.php-URL_ID=3107\&URL_DO=DO_TOPIC\&URL_SECTION=201.html

${ }^{37}$ Adeyemo A. B., (2011), E-government Implementation in Nigeria: An Assessment of Nigeria's e- Gov. Ranking, Journal of Internet and Information System, Vol. 2 (1) pp. 11-19. Available online at http://academicjournals.org/JIIS ISSN 1684-5315

${ }^{38} \mathrm{http}: / /$ www.firs.gov.ng/

${ }^{39} \mathrm{https}$ ://eirs.gov.ng/ retrieved $28^{\text {th }}$ December 2016

${ }^{40} \mathrm{http}$ ://www.firs.gov.ng/reforms-transformation/

${ }^{41} \mathrm{http}: / /$ data.worldbank.org/indicator/GC.TAX.TOTL.GD.ZS?locations=NG
} 


\begin{tabular}{|l|l|l|l|l|l|l|}
\hline Year & GDP & PPT & CIT & $\begin{array}{l}\text { CUS\&EXC } \\
\text { DUTY }\end{array}$ & VAT & TOTAL \\
\hline 2000 & 4727522 & 525100 & 51100 & 101500 & 58500 & 736200 \\
\hline 2001 & 5374339 & 639200 & 68700 & 170600 & 91800 & 970300 \\
\hline 2002 & 6232244 & 392200 & 89100 & 181400 & 108600 & 771300 \\
\hline 2003 & 6061700 & 683500 & 114800 & 195500 & 136400 & 1130200 \\
\hline 2004 & 11411067 & 1183600 & 113000 & 217200 & 159500 & 1673300 \\
\hline 2005 & 15610882 & 1904900 & 140300 & 232800 & 178100 & 2456100 \\
\hline 2006 & 18564595 & 2038300 & 244900 & 177700 & 221600 & 2682500 \\
\hline 2007 & 23280715 & 1600600 & 275300 & 241400 & 289600 & 2406900 \\
\hline 2008 & - & - & - & - & - & - \\
\hline 2009 & 24048480 & - & - & - & - & 219760 \\
\hline 2010 & 24712670 & - & - & - & - & 283000 \\
\hline 2011 & 24712670 & 998561 & 2041127 & 2437 & 259000 & 3301125 \\
\hline 2012 & 71491275 & 2352570 & 700000 & 5787 & 534698 & 3593055 \\
\hline & & & & & & \\
\hline
\end{tabular}

Table 1: GDP and Federal Tax Revenue Generated over the Years (N'Million)

Source: ${ }^{42}$

Research on the application of ICT in tax administration in developing counties by KFW Development Bank ${ }^{43}$, on integrated tax administration system ITAS the functions of ICT driven tax administration systems is highlighted as:

- $\quad$ Registration of taxpayer

- $\quad$ Return process

- $\quad$ Billing and collection process

- $\quad$ Tax payers accounting process

- $\quad$ On-line self service

- $\quad$ Revenue accounting process

- $\quad$ Case management processes

- $\quad$ Security processes.

${ }^{42}$ Ordu Promise and Anele Clement, (2015), A Performance Analysis of Nigerian Tax Actualization: Evidence of 20002012, International Journal of Management Sciences and Business Administration, Volume 1 Issue 6 May 2015 Pp 88$100 \mathrm{http}: / /$ researchleap.com/a-performance-analysis-of-nigerian-tax-objectives-actualization-evidence-of-2000-2012/

${ }^{43}$ Blume Jonas and Bott Maja, (2015), Information Technology in Tax Administration in Developing Countries, KFW Development Bank 


\section{Conclusion}

Much has been achieved through information technology to improve the Nigerian tax system. But for ICT application the milestones achievements that has been recorded would have been impossible. Yet more still needs to be done the by way of electronic administration, as some of the icons on the FIRS websites are yet to be functional. Only few states and local tax authorities have applied information technology in the proper sense of online services. Much of their activities is still based on the rule of the thumb.

The many years of single commodity revenue dependence as was the case with crude oil revenue, would need much of economic policy instruments to roll back economic dependence on petroleum sector. One policy that also helped to encourage many to get on board is government subsidies of local petroleum product sales which is characterized by falsification and corrupt practices. Economic policy instruments for preferred activities by way of tax relief or reduction in the areas of agriculture, packaging and industrialization to diversify the economy would have to be increased to encourage more investments in these areas that will increase employment and increase revenue by way of taxes (personal income tax and company tax).

The relationship between the benefit theory and cost of service principle of taxation is obvious in the state of infrastructural decay in some Nigerian capitals where infrastructure which tax deductions are supposed to provide for, is still sourced privately. Analysts have correlated this as resulting in the high incidence of tax avoidance. Citing Lagos state where there seem to be higher compliance in tax payments to the level of impacting infrastructural development in the state. So as much as governments look forward to increased tax levels people want to see evidence of what the taxes are doing especially in a country like Nigeria where there is suspicion of the government motives due to the perennial challenges of corruption and the resultant underdevelopment.

The challenges associated with jurisdiction in tax collection between the three tiers of government has to be checked despite the 1998 decree that spelt out spheres of tax collection of the various tiers, there are still controversies that has brought about many cases in the courts between states and federal government especially with VAT value added tax. ${ }^{44}$ These tax laws have to be reviewed and proper delineation drawn for the promotion of better understanding and relationship between this three tiers in relation to distributive justice, recognition and accommodation of differences in spheres of operation and procedural justice responsiveness and transparency ${ }^{45}$ in intergovernmental relationship Diamond (1974) all political institutions are intelligible in the light of the purpose or ends for which men device them to serve.

\subsection{Recommendations}

Accuracy in ICT application can bring about efficiency and equity which has been identified as the major principle of taxation. Effectively developed e-taxation system has the ability to eliminate the retinue of tax preparers, collectors, accountants, lawyers, auditors, security agents and consultants

\footnotetext{
${ }^{44}$ Asuquo Richard Gregory, (2014) Tax System in Nigeria: Issues and Challenges http://www.vanguardngr.com/2014/ 03/tax-system-nigeria-issues-challenges/ Retrieved $28^{\text {th }}$ December 2016

${ }^{45}$ Simeon Richard, Federalism and Social Justice: Thinking Through the Tangle in Greer Scott L. (Ed) Territory Democracy and Justice, Regionalism and Federalism in Western Democracies, New York USA, Palgrave Macmillan 2006
} 
used in a typical rule of the thumb style of tax collection. Here are some ways to enhance effective tax administration:

- Develop a common and uniformed strategy involving all stakeholders with regards to communication and implementations of tax policy.

- Improve and stabilize electricity generation which is the basis of e-connectedness.

- Develop a single end point electronic tax collection point that cannot be sabotaged thereby eliminating the collection of physical cash which are mostly not accounted for.

- $\quad$ Split up change initiatives in manageable bits with accurate information sent to tax payers.

- Functional ICT solutions should be implemented while language on the webpage should be as clear and simple, avoid unnecessary specialized administrative terminologies in the public domain. Some authors have recommended designs in local languages, but the problem with this is that Nigerian basic education is English. Majority of Nigerians learn to read and write in English language before their local languages.

- In tax design the ability to pay principle must be upheld so as to discourage tax avoidance.

- The principle of reward and punishment should be applied equitably in tax administration, just as authorities go after tax defaulters in punitive justice with all available resources, tax rebate should be given for tax compliance because the resources used to apply punitive justice can be costly so a little resource should be used to encourage more compliance, especially voluntary compliance like FACT Factual Accurate Complete and Timely.

- Public enlightenment on the use of ICT for tax payments has to be enhanced and some have recommended the re-introduction of the much needed civic education into primary and secondary schools by way of preparing citizens to be ready for their civic obligation to the government.

- $\quad$ ICT in tax administration has the potential to attract Foreign Direct Investment (FDI) as potential investors can see clearly tax administration and determine if it favourable for investment or not.

- Publication of tax defaulters on the web pages can serve as a deter rant as most corporations may not want to be so embarrassed.

- Importantly the Joint Tax Board must scout for and find out best tax practices that can be applicable to the Nigerian environment. Take for example the MOSS Systems for telecommunication broadcasting and electronic services adopted in Hungary and the European community for tax administration covering all member states. Here businesses registered in the European community can be administered through this one stop shop regardless of location of branches. The provision/purchase of the internet electronic machine which documents and records receipt transactions at source prevent to a large extent any form of manipulations. Customer's consciousness just has to be aroused to demand for their 
receipts. Also there is a page where questions bordering on tax administration can be asked and response given ${ }^{46}$

- It has become imperative for government to make internet access a key policy to guarantee broader equitable access of the public network. Wilsdon (2001)

\section{References}

[1] ABIOLA, J. and ASIWEH, M.: Impact of Tax Administration on the Government Revenue in a Developing Economy: A case Study of Nigeria, International Journal of Business and Social Science Vol. 3 No. 8Special Issue April, 2012.

[2] ADEYEMO, A. B.: E-government Implementation in Nigeria: An Assessment of Nigeria's eGov. Ranking, Journal of Internet and Information System, Vol. 2 (1) 11-19, 2011.

[3] ASUQUO, R. G.: Tax System in Nigeria: Issues and Challenges 2015 http://www.van guardngr.com /2014/03/tax-system-nigeria-issues-challenges/

[4] BLUME, J. and BOTT, M.: Information Technology in Tax Administration in Developing Countries, KFW Development Bank, 2015.

[5] BRUNSSON, N. and OLSEN, J. P.: Reforming Organization, Routledge London, 1993.

[6] COOLEY, T. M.: Remedies of Illegal Taxation. Am. L. Reg. 29, 1881, 1-16.

[7] CURRAN, J. D. (Ed.): Tax Philosophers: Two Hundred Years of Thought in Great Britain and the United States, The University of Wisconsin Press. London United Kingdom, 1974.

[8] DEACON, T. R.: The Political Economy of Natural Resource Curse: A Survey of Theory and Evidence. Now Publishers Incorporated. Hanover USA, 2011.

[9] ECONOMIC COMMISSION FOR EUROPE, Internet Infrastructural Development in Transition Economies New York and Geneva, United Nations, 2000.

[10] EKELUND, B. R. and WALKER, M. D.: On the Income Tax Exemption and Inheritance Taxes: The Evidence Considered, J. S. Mill, 1996.

[11] EKUNDARE, R.O.: An Economic History of Nigeria, 1860-1960:, Richard Clay the Chaucer Press Ltd. London Great Britain, 1973.

[12] GEOFFREY, B. and JAMES, M.: The Power to Tax, Analytical Foundation of Fiscal Constitution, Cambridge University Press New York USA, 1980.

[13] ICAN, Introduction to Nigerian Tax System.

\footnotetext{
${ }^{46} \mathrm{http}$ ://ec.europa.eu/taxation_customs/frequently-asked-questions/citizens-web-site-faq_en
} 
[14] ILESAMI, A.: A Historical Perspective of Petroleum on Nigeria's Economic Crisis since Independence, Global Journal of Human and Social Science. Inc. USA ISSN2249-460X EEconomics, 2015.

[15] KENDRICK, S.: Ability to Pay Theory of Taxation, America Economic Association, Vol. 29, No. 1, Mar., pp. 92-101, 1939, URL: http://www.jstor.org/stable/1806989

[16] KOGUT, B.: The Global Internet Economy, Cambridge Massachusetts MIT Press, London. 2000.

[17] LOPEZ, A. and KADAR, Z.: Introduction. International Tax Review: World Tax, 1st Jan, 2000, 6-11.

[18] MARJAN, A. (Ed): European Economic and Monetary Integration,. National University of Public Service, Budapest, Hungary, 2014.

[19] MALECKI, E.: Technology and Economic Development, Longman Scientific Tecnnical with John Wiley and Sons, New York, USA, 1991.

[20] MOULTON, R. S.: GDP and the Digital Econmy: Keeping up with the Changes, in BRYNJOFSSON, E. and KAHIN, B. (eds) Understanding the Digital Economy Data, Tools and Research. Cambridge Massachusetts, MIT Press. London, 2000.

[21] MOKYR, J.: The Gift of Anthenna, Historical Origins of Knowledge Economy, Oxford Princeton University Press United Kingdom, 2002.

[22] NDUBUTO, I. N. et'al: Competitiveness and the Determinants of Cocoa Export from Nigeria, 2010, http://www.sciencepub.net/report/report0207/08_3470report0207_51_54.pdf.

[23] NEGEDU, I. and ATABOR, A.: Nationalism in Nigeria; A Case of Patriotic Citizenship, American Journal of Contemporary Research, Vol. 5, No.3, June 2015, Retrieved $12^{\text {th }}$ June 2016.

[24] NIGHTINGALE, K.: Taxation theory and practices, Pearson Education Ltd., England, 2002.

[25] OECD, Fundamental principles of taxation, in Addressing the Tax Challenges of the Digital Economy, 2014.

[26] OLUKOJU, K.: The United Kingdom and the Political Economy of Global Oils and Fat Business during the 1930, Journal of Global History, Vol. 4, (1) 1, 2009.

[27] OLUWASUNMI, H.A.: Agriculture and Nigerian Economic Development, Ibadan, Oxford University Press, London, 1960.

[28] ORDU, P. and ANELE, C.: A Performance Analysis of Nigerian Tax Actualization: Evidence of 2000- 2012, International Journal of Management Sciences and Business Administration, Volume 1, Issue 6, May, 2015, pp 88-100, http://researchleap.com/a-performance-analysis-ofnigerian-tax-objectives-actualization-evidence-of-2000-2012/ 
[29] OSAGIE, J. and IKPOMWONSA, F.: Craft, Guild and the Sustenance of Pre-colonial Benin Kingdom, International Journal of Arts and Humanities, (IJAH) Bahir-Dar Ethiopia Vol. 4(1), S/No 13, January, 2015, p.1-17, http://www.ajol.info/index.php/ijah/article/view/113901 retrieved $24^{\text {th }}$ December 2016.

[30] OSENI, M.: Sustenance of Tax Administration by Information and Communication Technology in Nigeria, Archives of Business Research 4 (1), 2015, p.47-54.

[31] OSUKOYA, D.: Nigeria Tax system needs autonomy, 2009. Retrieved 19th Dec. Available from: http://234next.com/csp/cms/sites/Next/Money/Finance/5499086-147/story.csp.

[32] OYEDELE, J.O.: Enhancing the Sustainability of Cocoa Growing in Nigeria. A Paper Presented at the ICCO Roundtable Congress on Sustainable World Cocoa Economy at Accra, Ghana, 2007, $3^{\text {rd }}-6^{\text {th }}$ October.

[33] PAUL, I. A.: A Historical Perspective of Petroleum on Nigeria's Economic Crisis since Independence, Global Journal of Human and Social Science, 2015, retrieved $20^{\text {th }}$ December, 2016.

[34] ROSS, M.: The political economy of the resource curse, World Politics 1/1, 1999, p.297-322, Rifkin J.: The Age of Access, New York, Penguin Putnam Incorporated, 2000.

[35] SIMEON, R.: Federalism and Social Justice: Thinking through the Tangle in GREER S. L. (Ed) Territory Democracy and Justice, Regionalism and Federalism in Western Democracies, Palgrave Macmillan, New York USA, 2006.

[36] STIGLITZ, J.: Development-Oriented tax policy in Gordon Roger H., (Ed), Taxation in Developing Countries, Six Case Studies and Policy Implications, New York, Columbia University Press, 2010.

[37] Taxes Levies Approved (list of collection) Decree № 21 of 1998 Laws of the Federation FGN

[38] THOMAS, C. M. A.: Treaties of Law of Taxation: Including the Laws of Local Assessments, Chicago, Callaghan, 1879, http://www.businessdictionary.com/definition/taxation.html

[39] UDO, R.K.: British Policy and the Development of Export Crops in Nigeria, Nigerian Journal of Economic and Social Studies, 9, 2, 1967, retrieved 12 ${ }^{\text {th }}$ December, 2016.

[40] WILSDON, J.: Digital Futures, Earthscan Publications Ltd, United Kingdom, 2001

[41] YOHANNES, M. and SISAY, B.: General Theories and Principles of Taxation, http://www.abyssinialaw.com/study-on-line/item/1066-general-theories-and-principles-oftaxation, retrieved $29^{\text {th }}$ November, 2016. 